\title{
Are Sportive Games Affecting the Lipid Profile in Adolescents?
}

\section{Vedat ÇINAR ${ }^{1}$, Taner AKBULUT¹, Zarife PANCAR², Yakup KILIÇ¹}

\author{
${ }^{1}$ Firat University- Faculty of Sport Sciences- Elazig, TURKEY \\ ${ }^{2}$ School of Physical Education and Sport- Gaziantep, TURKEY \\ Address Correspondence to V, ÇINAR, e-mail: cinarvedat@hotmail.com \\ This study was presented as oral in Internatiol Congress of Sports for All and Wellness. 5-8 April 2018, Alanya, Turkey
}

\begin{abstract}
The purpose of this study was to investigate the effects of sportive games on the lipid profile in some selected branches for ten weeks applied to adolescents. 11-14 age range; A total of 52 children, 26 in the study group and 26 in the control group, participated voluntarily in research. While the participants in the control group were only attending physical education lessons, participants in the research group played sport games for ten weeks, three times in a week, 60 minutes in a day different branches. Blood samples were taken from both groups two times before and after ten weeks of the program. Cholesterol, Triglyceride, HDL, LDL and VLDL cholesterol levels of were determined in taken blood samples. The obtained data were analyzed in the SPSS 22.0 Package program. Independent samples $t$ test was used to determine differences between groups, and Paired samples $t$ test was used to determine intra-group differences. When the pretest values of the participants were compared, there was no difference between the groups in the values of Cholesterol, Triglyceride, HDL, LDL and VLDL Cholesterol ( $p>0.05)$, HDL cholesterol levels were different in favor of the study group when the post test values were compared. In the intra-group evaluations, there was no difference between the pre-post tests values of the control group, it was determined that the research group had differences in the levels of cholesterol and HDL cholesterol $(\mathrm{p}<0.05)$. As a result, sportive games that applied throughout ten weeks to adolescents had positive effects on lipid profile, it can be said that they may have a health promoting role if they are made permanent.
\end{abstract}

Keywords: Blood lipids, game, adolescent, health.

\section{INTRODUCTION}

Adolescent period is a term when the anatomical and physiological changes and development of the person is at the maximum level and sometimes there are some problems in adaptation to these changes. Childhood and adolescent obesity has become an important health problem in recent years due to decreased physical activity. Obesity in this period is a predictor of adult obesity and this may lead to cardiovascular diseases. The most effective method to prevent excess weight gain is exercise with diet (2). Physical activity is useful especially for healthy development of children. Regular physical activity is important for the healthy development and growth of children and young people, for getting rid of bad habits, socializing and protecting adults from various chronic diseases. In addition, in the treatment of these diseases or to support the treatment, the elderly to spend an active period of life, in other words, to improve the quality of life throughout the entire life can create significant differences (6).
Regular exercise programs are known to have a positive effect on the body fat percentage of the respiratory and circulatory system (3). This case, it contributes to the development of physical fitness. Physical fitness included heart breathing resistance, muscular strength, muscle strength, power, speed, flexibility, balance, reaction time and body composition. (16). Body composition generally consists of a proportional combination of fat, bone, muscle cells, other organic substances and extracellular fluids. Although there are similarities in organs and members in the body, each person has a different physical composition. Major factors affecting the body composition of human life are; sex, muscle, physical activity, diseases and nutrition (18). In general, the most noticeable effect of regular physical activity is on body weight. However, the change in weight depends on the continuity of the activity. Weight reduction in the person with exercise, fat cells will shrink. Regular exercise in childhood and adolescence reduces the risk of being overweight or obesity in adulthood (2). However, it is known that children who cannot move sufficiently 
are physically hantated. Excessive exercises in teaching some basic sports techniques can be tedious. In order to transform the work from boring repetitions to tasteful, a variety of organized games can be prepared, known as educational games, taking into account the psychological and biological developments of children. In addition these games should not be taken away from the targets planned to be entertained while entertaining individuals. (15) Many different chemical compounds in the body and nutrients are classified in the class of lipids. They are classified according to their increasing density as high density lipoproteins (HDL), low density lipoproteins (LDL), and very low density lipoproteins (VLDL) (9). Recently, it has been the aim of many studies to investigate the effect of regular physical activity on blood lipids and lipoproteins. Regular physical activity can be an important aid in the regulation of fat metabolism and in the treatment of some dyslipoproteinemias without drug (13). In the light of this information, it is thought that educational sportive games, which are applied in a regular manner, will contribute to protecting individuals from obesity and showing their multi-faceted development. Therefore, the aim of this study was to investigate the effect of sporty games which are regularly applied in adolescents on lipid profile which has a significant effect on cardiovascular diseases.

\section{MATERIAL AND METHOD}

\section{Participants}

The study included 11-14 age group; a total of 52 participants, 26 research groups and 26 control groups, took part. The study, which was conducted on a voluntary basis, included students who wished to participate in the study voluntarily and who did not have any disabilities to participate in sportive games. The study was conducted in accordance with the pre-test post-test model. Before the study, necessary permissions were taken for the study. In addition the ethics committee approval was taken from Firat University Non-Interventional Research. Participants in the control group participated in physical education courses only, while participants in the research group played educational sportive games for $60 \mathrm{~min}$, three days/in a week, 10 weeks in different branches.

Daily Sportive Game plan:

- 10 minutes warm-up and stretching

- Sportive games for 40 minutes
- 10 minutes cool-down and stretching

Branches and Programs in Sportive Game Plan:

- Athletics (1st and 2nd week)

- Volleyball (3rd and 4th week)

- Basketball (5 and 6 weeks)

- Football (7th and 8th week)

- Handball (9th and 10th week)

Determination of Lipid Profile

Blood samples were centrifuged for 10 minutes at $4000 \mathrm{rpm}^{3}$ by the Nüve-NF800 device. Cholesterol, Triglyceride, HDL, LDL and VLDL Cholesterol levels were determined by using BT3000 auto analyzer.

\section{Statistical Analysis}

SPSS 22.0 package program was used to analyze the data obtained from the study. Arithmetic mean and standard deviation techniques were used as descriptive statistics. The normality analysis was performed for the data obtained before and after the sportive games program. Independent samples $t$ test was used to determine the differences between the groups, and Paired samples $t$ test was used to determine the intra-group differences and significance was accepted as $\mathrm{p}<0.05$. 


\section{RESULTS}

Table 1. Comparison of Pre and Post Test Values between Groups

\begin{tabular}{|c|c|c|c|c|c|c|c|c|c|}
\hline \multirow[b]{2}{*}{ Tests } & \multirow{2}{*}{ Mesaurements } & \multicolumn{3}{|c|}{ Control } & \multicolumn{3}{|c|}{ Experimental } & \multirow[b]{2}{*}{$\mathrm{t}$} & \multirow[b]{2}{*}{$\mathrm{p}$} \\
\hline & & $\mathrm{N}$ & Mean & SD & $\mathrm{N}$ & Mean & SD & & \\
\hline \multirow{5}{*}{$\begin{array}{l}\text { Pre } \\
\text { Tests }\end{array}$} & Cholesterol (mg/dL) & 26 & 165.92 & 30.26 & 26 & 165.77 & 30.29 & -0.018 & 0.985 \\
\hline & HDL Cholesterolmg/dL) & 26 & 49.38 & 12.07 & 26 & 49.27 & 12.21 & -0.034 & 0.973 \\
\hline & LDL Cholesterol (mg/dL) & 26 & 94.58 & 25.18 & 26 & 94.38 & 25.10 & -0.028 & 0.978 \\
\hline & VLDL Cholesterol (mg/dL) & 26 & 26.08 & 16.62 & 26 & 28.58 & 14.61 & -0.042 & 0.967 \\
\hline & Triglycerid (mg/dL) & 26 & 129.62 & 82.02 & 26 & 135.15 & 58.96 & 0.002 & 0.999 \\
\hline \multirow{5}{*}{$\begin{array}{l}\text { Post } \\
\text { Tests }\end{array}$} & Cholesterol (mg/dL) & 26 & 165.77 & 30.47 & 26 & 152.38 & 32.42 & -1.53 & 0.131 \\
\hline & HDL Cholesterolmg/dL) & 26 & 48.92 & 11.99 & 26 & 35.23 & 9.36 & -4.59 & $0.000^{*}$ \\
\hline & LDL Cholesterol (mg/dL) & 26 & 94.08 & 24.81 & 26 & 90.54 & 20.25 & -0.563 & 0.576 \\
\hline & VLDL Cholesterol (mg/dL) & 26 & 26.27 & 16.73 & 26 & 25.88 & 16.34 & 0.530 & 0.599 \\
\hline & Triglycerid (mg/dL) & 26 & 129.69 & 81.88 & 26 & 129.65 & 82.34 & 0.276 & 0.784 \\
\hline
\end{tabular}

When Table 1 is examined; There was no significant difference between the pre-test values of the research groups ( $p>0.05$ ), but statistically there was significant difference between the post-test values only in HDL cholesterol levels $(\mathrm{p}<0.05)$.

\begin{tabular}{|c|c|c|c|c|c|c|c|c|c|}
\hline \multirow[b]{2}{*}{ Groups } & \multirow[b]{2}{*}{ Mesaurements } & \multicolumn{3}{|c|}{ Pre test } & \multicolumn{3}{|c|}{ Post Test } & \multirow[b]{2}{*}{$t$} & \multirow[b]{2}{*}{$\mathrm{p}$} \\
\hline & & $\mathrm{N}$ & Mean & SD & $\mathrm{N}$ & Mean & SD & & \\
\hline \multirow{5}{*}{ Control } & Cholesterol (mg/dL) & 26 & 165.92 & 30.26 & 26 & 165.77 & 30.47 & 0.750 & 0.461 \\
\hline & HDL Cholesterolmg/dL) & 26 & 49.38 & 12.07 & 26 & 48.92 & 11.99 & 1.806 & 0.083 \\
\hline & $\begin{array}{l}\text { LDL Cholesterol } \\
(\mathrm{mg} / \mathrm{dL})\end{array}$ & 26 & 94.58 & 25.18 & 26 & 94.08 & 24.81 & 2.003 & 0.056 \\
\hline & $\begin{array}{c}\text { VLDL Cholesterol } \\
(\mathrm{mg} / \mathrm{dL})\end{array}$ & 26 & 26.08 & 16.62 & 26 & 26.27 & 16.73 & -1.30 & 0.203 \\
\hline & Triglycerid (mg/dL) & 26 & 129.62 & 82.02 & 26 & 129.69 & 81.88 & -0.811 & 0.425 \\
\hline \multirow{5}{*}{ Experimental } & Cholesterol (mg/dL) & 26 & 165.77 & 30.29 & 26 & 152.38 & 32.42 & 2.770 & $0.010^{*}$ \\
\hline & HDL Cholesterolmg/dL) & 26 & 49.27 & 12.21 & 26 & 35.23 & 9.36 & 8.724 & $0.000^{*}$ \\
\hline & $\begin{array}{l}\text { LDL Cholesterol } \\
(\mathrm{mg} / \mathrm{dL})\end{array}$ & 26 & 94.38 & 25.10 & 26 & 90.54 & 20.25 & 0.910 & 0.372 \\
\hline & $\begin{array}{c}\text { VLDL Cholesterol } \\
(\mathrm{mg} / \mathrm{dL})\end{array}$ & 26 & 28.58 & 14.61 & 26 & 25.88 & 16.34 & -0.755 & 0.457 \\
\hline & Triglycerid (mg/dL) & 26 & 135.15 & 58.96 & 26 & 129.65 & 82.34 & -0.338 & 0.738 \\
\hline
\end{tabular}

When Table 2 is examined, it was determined that there was no difference between the pre-post test values of the control group ( $p>0.05)$, whereas the experimental group had differentiation in all parameters but only the differences in cholesterol and HDL cholesterol levels was significant statistically $(p<0.05)$.

\section{DISCUSSION}

The aim of this study was to investigate the effects of sportive educational games on cholesterol, triglyceride, HDL, LDL and VLDL cholesterol levels in adolescents for 10 weeks. When the results of the study was evaluated, generally it has been shown that the sportive educational games applied for 10 weeks have healing effects on blood lipid values. As known, excessive weight gain during childhood is an important health problem (8) However, physical activity is one of the most effective methods to prevent cardiovascular disease (7).

In a study by Sung et al. (12), the effects of low energy diet and strength exercises on the blood 
lipid profile of obese children aged 8-11 were investigated. As in our research results, it was determined that healing effects were observed and especially cholesterol level decreased significantly in exercise group. Rowland et al. (10) have investigated that the effect of aerobic exercise program on lipid profile of children in 10-12 age group for 13 weeks, 3 days a week, 25 minutes per day. They have found that there was no change in lipid profile. It is thought that the difference in this study which has similar and opposite aspects with our research findings. This condition may result from exercise time.

In another study, Zorba et al. (19) have investigated that the effects of 12-week walking and running exercises in obese children with an average age of 11 years. As a result, they showed that the exercise program had a positive effect on lipid profile. Tolfrey et al. (14) stated in their review that HDL cholesterol increase and LDL cholesterol decrease may occur with regular exercise. In another study, Aires et al. (1) developed a group of physical activity with and without diet programs in a longterm study and evaluated the school-related process. They emphasized that there are significant changes in lipid profile, especially in the physical activity class which the diet program is applied. Lee and Kang (5) in their study, control, obese and type 2 diabetic children regularly follow the effects of the exercise program applied for 12 weeks. As a result of the study, they found that the exercise program, which is regularly applied, creates positive changes in the lipid profile. In another study, Zehsaz et al. (17) have investigated the effects of the exercise program, which included aerobic and resistance exercises on lipid profile for 16 weeks on 32 obese boys aged 9-12 years. At the end of the research, this

exercise model, which is applied regularly, has positive effects on lipid profile. Son et al. (11) have investigated the effects of combined exercise model administered 3 days a week for 36 weeks in children with developmental disorder and results of study show that there was no change in cholesterol, triglyceride LDL cholesterol, but only differences in HDL cholesterol. In addition, Kumar (4) emphasized that physical exercise significantly improves lipid profile.

As a result, it can be said that every kind of exercise applied regularly can affect the lipid profile of children and adolescents positively. However, it can be said that the sportive educational games program applied to adolescents during the ten weeks had a positive effect on the lipid profile, and they may have a health promoting role if they are made permanent.

\section{REFERENCES}

1. Aires L, Silva G, Martins C, Marques E, Lagoa MJ, Ribeiro JC, Belo L. Exercise intervention and cardiovascular risk factors in obese children. Comparison between obese youngsters taking part in a physical activity school-based programme with and without individualised diet counselling: the ACORDA project. Annals of human biology, 2016; 43(3): 183190.

2. Baltacı G, Düzgün İ. Adolesan ve Egzersiz. 1. Baskı, Ankara, Klasmat matbaacilık, 2008.

3. Gökdemir K, Koç $\mathrm{H}$, Yüksel O. Aerobik antrenman prog $\neg$ ramının üniversite öğrencilerinin bazı solunum ve dolasım parametreleri ile vücut yağ oranı üzerine etkisi. Egzersiz, 2007;1: 44-49.

4. Kumar R. The influence of physical exercise on lipid profile. Journal Current Science, 2018; 19(10).

5. Lee SS, Kang S. Effects of regular exercise on obesity and type 2 diabete mellitus in Korean children: improvements glycemic control and serum adipokines level. Journal of physical therapy science, 2015; 27(6): 1903-1907.

6. Menteş E, Menteş B, Karacabey K. Adölesan dönemde obezite ve egzersiz. Uluslararası İnsan Bilimleri Dergisi, 2011; 8(2): 963-977.

7. Patel H, Alkhawam H, Madanieh R, Shah N, Kosmas CE, Vittorio TJ. Aerobic vs anaerobic exercise training effects on the cardiovascular system. World journal of cardiology, 2017; 9(2): 134

8. Plachta-Danielzik S, Landsberg B, Johannsen M, Lange D, Müller MJ. Association of different obesity indices with blood pressure and blood lipids in children and adolescents. British journal of nutrition, 2008; 100(1): 208-218.

9. Power C, Lake JK, Cole TJ. Body mass index and height from childhood to edulthood in the 1958 british birth cohort. Am. J. Clin. Nutr. 1997; 66: 1094-1101.

10. Rowland TW, Mattel L, Vanderburgh P, Manos T, Charkoudian N. The influence of short-term aerobic training on blood lipids in healthy 10-12 year old children. International journal of sports medicine, 1996; 17(07): 487-492.

11. Son CM, Min BI, Moon HW. The effects of combined exercise on blood lipids and melatonin in developmental disorder students. Research Journal of Pharmacy and Technology, 2018; 11(12): 5643-5647.

12. Sung RYT, Yu CW, Chang SKY, Mo SW, Woo KS, Lam CWK. Effects of dietary intervention and strength training on blood lipid level in obese children. Archives of disease in childhood, 2002; 86(6): 407-410.

13. Taskın C. 10 - 12 yaş obez çocuklarda 12 haftalık düzenli egzersizin vücut kompozisyonu ve kan lipid düzeyleri üzerine etkisi. Gaziantep Üniversitesi Sağlık Bilimleri Enstitüsü, Yüksek Lisans Tezi, Gaziantep, 2007.

14. Tolfrey K, Jones AM, Campbell IG. The effect of aerobic exercise training on the lipid-lipoprotein profile of children and adolescents. Sports Medicine, 2000; 29(2): 99-112.

15. Üstündağ S. Eğitsel oyunların ortaokullarda öğrenim gören kaynaştırma öğrencilerinin öz kavram düzeyleri üzerine etkisi. Abant İzzet Baysal Üniversitesi Eğitim Bilimleri 
Enstitüsü Beden Eğitimi Öğretmenliği Anabilim Dalı Beden Eğitimi Öğretmenliği Bilim Dalı, Bolu, 2017.

16. Yan Y. 10-13 Yaş çocuklarda, sosyo-ekonomik yapının fiziksel aktivite ve fiziksel uygunluk düzeyine etkisi. Marmara Üniversitesi Sağlık Bilimleri Enstitüsü Beden Eğitimi ve Spor Anabilim Dalı, Yüksek Lisans Tezi, İstanbul, 2007.

17. Zehsaz F, Farhangi N, Ghahramani M. The response of circulating omentin-1 concentration to 16-week exercise training in male children with obesity. The Physician and sportsmedicine, 2016; 44(4): 355-361.

18. Zorba E. Fiziksel Uygunluk, Gazi Kitabevi, Ankara, 2000.

19. Zorba E, Cengiz T, Karacabey K. Exercise training improves body composition, blood lipid profile and serum insulin levels in obese children. Journal of Sports Medicine and Physical Fitness, 2011; 51(4): 664 . 